\title{
Om samvalg og andre sam-ord
}

\author{
Samvalg anbefales som norsk avløserord for «shared decision making», det å involvere pasienter aktivt \\ i avgjørelser om behandling og andre tiltak i helsetjenesten. Samvalg føyer seg inn i en lang rekke av \\ sam-ord i helsetjenesten.
}

Samtidig som særskriving, deling av sammensatte ord, brer om seg i norsk språk, skapes jevnlig nyord ved hjelp av sammensetninger. Ofte gjenbrukes forstavelser (prefiks) i slike sammensetninger. Forstavelsen sam-, som brukes om interaksjoner og fellesskap, inngår i en rekke ord og begreper knyttet til medisin og helsetjenester.

Begrepet samsykdommer ble ifølge professor Peter F. Hjort (1924-2011) skapt på landsmøtet til Nasjonalforeningen for folkehelsen på Lillehammer i juni 1981 (1). I en diskusjon om sykdomsbegrep og psykososiale problemer ble en «ny sykdomsgruppe» betegnet som samsykdommer fordi de var knyttet til ord som samliv, samarbeid, samvær og samfunn. Senere ble samsykdommer mer formelt definert som en «samlebetegnelse for medisinske tilstander som springer ut av problemer i forholdet mellom mennesker, dvs. i samfunn og samliv» (2).

Samhandlingsreformen (3) som ble iverksatt fra 2012, har som mål å forbedre samarbeid og samhandling mellom ulike deler av helsetjenesten. Fra samme år ble også samkommune, et formelt, forpliktende samarbeid mellom norske kommuner for å løse felles oppgaver f.eks. innen helse og omsorg, tillatt etter kommuneloven.

Blant andre, nyere sam-ord med helserelevans er samsoving, det at spedbarn sover i samme seng som foreldrene. Og i pasientsikkerhetsarbeidet er samstemming av legemidler et satsingsområde. Det er betegnelsen på en gjennomgang av pasienters legemiddelbruk ved hjelp av ulike kilder som pasientens egen oversikt, pleie- og omsorgstjenestens liste og fastlegens og sykehusets journaler.

\section{Samvalg}

På et møte om brukermedvirkning i Nasjonalt kunnskapssenter for helsetjenesten i mai 2014 ble begrepet samvalg lansert av brukerrepresentant og sykepleier Simone Kienlin og psykiater Øystein Eiring ved Sykehuset Innlandet (4). Ordet er benyttet noen ganger tidligere av de samme personene og i de samme miljøene $(5,6)$. Samvalg er et norsk avløserord for det engelske «shared decision making» og en betegnelse på avgjørelser som tas av behandler og pasient i fellesskap, også kalt veiledet valg, og prosessen med å komme frem til avgjørelsen.

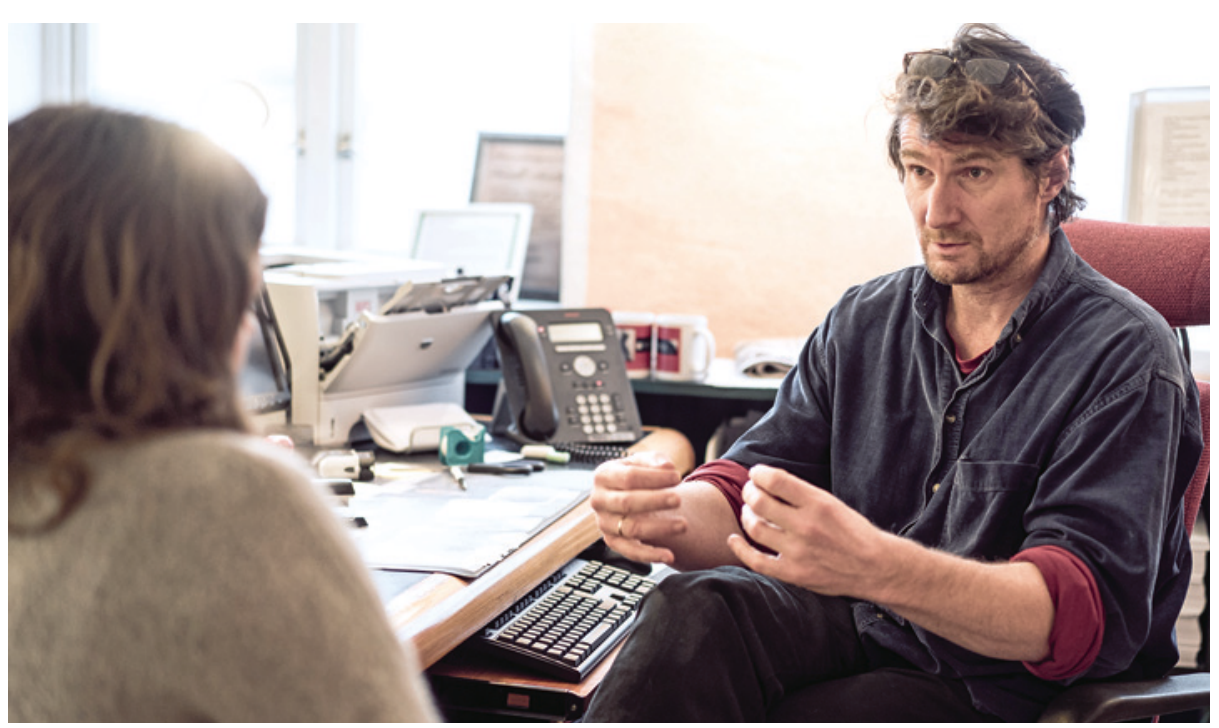

Illustrasjonsfoto: Ole Kristian Losvik

Pasientmedvirkning og brukerorientering er stadig viktigere verdier i helsetjenesten. Samvalg er blitt definert som «en tilnærming der lege og pasient deler den beste, tilgjengelige kunnskap når beslutninger skal tas, og der pasienten støttes i å vurdere ulike alternativer, for å kunne gjennomføre et informert valg» (7). Motivasjon og god vilje er ikke tilstrekkelig for å gjennomføre slike samvalg. Det forutsetter både kunnskap og ferdigheter om prosessen. Det er utviklet en tretrinnsmodell for samvalg for helsepersonell (8), og det arbeides med å lage egne, nettbaserte verktøy for slik beslutningsstøtte.

Samvalg er et eksempel på norske nyord som fyller behovet for betegnelser på nye fenomener. Ordet er kort, det er dekkende og det er beslektet med andre sam-ord innen helsetjenesten. Derfor anbefales det.

\section{Magne Nylenna}

magne.nylenna@kunnskapssenteret.no

Nasjonalt kunnskapssenter for helsetjenesten

Magne Nylenna (f. 1952) er direktør ved Nasjonalt kunnskapssenter for helsetjenesten, professor II i samfunnsmedisin ved Universitetet i Oslo og Norges teknisk-naturvitenskapelige universitet, og redaktør av Medisinsk ordbok.
Litteratur

1. Hjort PF. Om samsykdommer. I: Hjort PF. Helse for alle! Foredrag og artikler 1974-93. Oslo: Statens institutt for folkehelse, 1994: 75-85. www.nb.no/nbsok/nb/ 82ad36abaf2e3102864486c41d176961 ?index $=2 \# 0$ (1.10.2014).

2. Norges forskningsråd. Medisin og helse anno 2020 - en forskningsodyssé. Oslo: Norges forskningsråd, 2000.

3. St.meld. nr. 47 (2008-2009). Samhandlingsreformen. Rett behandling - på rett sted - til rett tid. www.regjeringen.no/nb/dep/hod/dok/regpubl/ stmeld/2008-2009/stmeld-nr-47-2008-2009html?id=567201 (16.10.2014).

4. Pasient vil ha et ord med i laget. Kunnskapssenteret 7.5.2014. www.kunnskapssenteret.no/nyheter/ pasient-vil-ha-et-ord-med-i-laget (30.9.2014).

5. Øiern T. ROP-pasienter kan få hjelp til å stumpe røyken. Sykehuset Innlandet 18.9.2012. www.rop.no/artikler/Etter dato/rop-pasienterkan-faa-hjelp-til-aa-stumpe-roeyken (1.10.2014).

6. Løberg AK. - Tilpassa kreftbehandling redda livet mitt. NRK Hedmark og Oppland 3.3.2014. www.nrk.no/ho/tror-pa-tilpassa-kreftbehandling1.11580615 (1.10.2014).

7. Elwyn G, Laitner S, Coulter A et al. Implementing shared decision making in the NHS. BMJ 2010; 341: c5146.

8. Elwyn G, Frosch D, Thomson R et al. Shared decision making: a model for clinical practice. J Gen Intern Med 2012; 27: 1361-7.

Mottatt 6.10.2014 og godkjent 16.10. 2014. Redaktør Marit Skaar Fjellhaug. 